\title{
Hepatitis B surface antigen (HBsAg) in the liver of patients with hepatitis: a comparison with serological detection
}

\author{
M. B. RAY, V. J. DESMET, J. FEVERY, J. DE GROOTE, A. F. BRADBURNE, \\ AND J. DESMYTER \\ From the Laboratory of Histochemistry and Cytochemistry and the Division of Hepatology \\ (Department of Medical Investigation) and the Viral Diseases Laboratory (Department of Human Biology), \\ Akademisch Ziekenhuis Sint Rafaël, University of Leuven, B-3000 Leuven, Belgium
}

SYNOPSIS Chronic hepatitis was diagnosed on liver biopsy of 76 patients; $52(68 \%)$ had HBsAg. Of the 52 patients with HBsAg, $23 \%$ had HBsAg shown by immunofluorescence on the liver, while it could not be detected with radioimmunoassay on the serum; 77\% had $\mathrm{HBsAg}$ detectable in liver and in serum, and none had HBsAg in serum only. HBsAg was detected more frequently in chronic aggressive hepatitis and active cirrhosis than in chronic persistent hepatitis and cirrhosis with little activity. No correlation was found in the different forms of chronic hepatitis between the $\mathrm{HBsAg}$ status on the one hand, and levels of transaminases, gammaglobulins, and auto-antibodies on the other.

Acute hepatitis was diagnosed on liver biopsy of 24 patients; 50\% had HBsAg. Liver tissue positivity was very low in the fully developed stage compared to serum positivity. In 146 patients with other liver ailments, both liver and serum were negative for $\mathrm{HBsAg}$.

The specific association between HBsAg (hepatitis B surface antigen) and viral hepatitis type $B$ has been firmly established. Wide variations have been found in the incidence of $\mathrm{HBs} \mathrm{Ag}$ in the serum of patients with acute (Shulman and Barker, 1969; Prince et al, 1970; Edgington and Ritt, 1971; Mossor-Ostrowska et al, 1974) and chronic (Sutnick et al, 1969; Velasco and Katz, 1970; Wewalka et al, 1970) hepatitis. The frequency of HBsAg in chronic hepatitis as estimated in the blood varies from 3\% in Australia (Cooksley et al, 1972) to $62 \%$ in Austria (Wewalka et al, 1970). The variation in the reported incidence of $\mathrm{HBsAg}$ may be due to differences in the geographical prevalence of $\mathrm{HB}$ virus infection (Cooksley et al, 1972) and to differences in the technique used for estimation (Prince, 1971).

In liver tissue, the antigen was consistently detected by immunofluorescence in various forms of chronic hepatitis with HBsAg (Hadziyannis et al, 1972; Krawczyński et al, 1972), suggesting that immunofluorescence on the liver may compete with serology in ability to detect HBsAg in those patients. There are conflicting reports regarding the detec-

Received for publication 26 August 1975 tion of HBsAg in liver tissue of acute hepatitis with circulating HBsAg (Coyne et al, 1970; Cérat et al, 1973; Krawczyński et al, 1972; Mossor-Ostrowska et al, 1974; Gudat et al, 1975). In the present study, we compare immunofluorescent detection of HBsAg in the liver of biopsy-proven hepatitis with results of detection in the serum by radioimmunoassay, the most sensitive method available (Ling and Overby, 1972), and we compare the HBsAg status with the presence of various histological forms of hepatitis; in chronic hepatitis, we have also tried to correlate the HBsAg status and the histological type of disease with sex, gammaglobulin, and transaminase values, and the presence of auto-immune antibodies.

\section{Material and Methods}

\section{PATIENTS AND DIAGNOSIS}

Two hundred and forty-six liver biopsies were collected from patients submitted to needle biopsy during the last two years (December 1972 to December 1974) for various hepatic dysfunctions. The patients were mostly adults of Belgian origin. Biopsies were taken with a modified Vim-Silverman needle (Rake et al, 1969). The greater part of the 
biopsy cylinder was used for routine histological diagnosis and the remaining part (approx. $5 \mathrm{~mm}$ ) was processed for indirect immunofluorescence. One or more serum samples were taken during or within one week of the collection of the biopsy. Depending on the hepatic morphology, the patients were classified as acute or chronic hepatitis. Each main group was further subdivided into different subgroups on the basis of previously described morphological variations within the main groups (De Groote et al, 1968; Bianchi et al, 1971).

Chronic hepatitis without cirrhosis was subdivided into chronic persistent hepatitis, mainly characterized by portal inflammation, and chronic aggressive hepatitis, with periportal inflammation (piecemeal necrosis).

Cirrhosis was classified as cirrhosis with little activity when the degree of inflammation was histologically comparable to chronic persistent hepatitis, and as active cirrhosis when the histology displayed inter alia piecemeal necrosis as in chronic aggressive hepatitis. This group of patients does not always present clinically as what has been described under the headings 'active chronic hepatitis' or 'chronic active liver disease', which are mainly based on the serum levels of transaminases and $\gamma$ globulins and the presence of clinical and laboratory signs of immunological disturbances.

Acute hepatitis was subdivided into four categories. The 'fully developed stage of acute hepatitis' (Bianchi et al, 1971) comprised seven patients, in whom the biopsy was taken one to six weeks (average five weeks) after the clinical onset of the disease. The 'later stage of acute hepatitis' (Bianchi et al, 1971) comprised nine patients; five of these had no apparent clinical symptoms of acute hepatitis and were submitted to liver biopsy because of the incidental discovery of raised transaminase levels (five times above the normal value); the remaining four patients had an acute disease lasting 8 to 20 weeks (average 16 weeks) before biopsy was taken. The 'residual stage of acute hepatitis' (Bianchi et al, 1971) comprised three patients biopsied 8 to 30 weeks (average 20 weeks) after the clinical onset of the disease.

'Acute hepatitis with signs of possible transition to $\vec{\nabla}$ chronicity' (Bianchi et al, 1971; Desmet, 1973) is a histological entity combining lobular features of $\infty$ acute hepatitis together with periportal hepatitis $\vec{\circ}$ (piecemeal necrosis). This group comprised five $\overrightarrow{\vec{\omega}}$ patients biopsied 1 to 35 weeks (average 13 weeks) after the clinical onset.

\section{IMMUNOFLUORESCENCE}

HBsAg was detected in the liver biopsies by the indirect immunofluorescence method. The technical aspects including the various immunochemicals used were described earlier (Ray et al, 1974).

\section{SEROLOGY}

In each serum sample HBsAg was determined by solid phase radioimmunoassay (Ausria); doubtful positives were checked with the RIA neutralization test (Bradburne and Desmyter, 1974). Sera from each patient were also assayed for auto-antibodies, ie, antinuclear factors (ANF), antimitochondrial antibodies (AMA), and smooth muscle antibodies (SMA) by indirect immunofluorescence.

\section{Results}

Of the 246 liver biopsies examined, 100 were from patients with histologically proven acute or chronic hepatitis, and 146 were from patients with a wide variety of other liver disorders. The histological diagnoses and results of immunofluorescence and circulating $\mathrm{HBsAg}$ are given in table $\mathrm{I}$; further results on chronic hepatitis patients are given in table II. The biopsies in each subgroup of patients were divided into four categories: liver and serum positive,

\begin{tabular}{|c|c|c|c|c|c|c|c|}
\hline Histological Diagnosis & Number & $\begin{array}{l}\text { Liver }+ \\
\text { Serum }+\end{array}$ & $\begin{array}{l}\text { Liver + } \\
\text { Serum - }\end{array}$ & $\begin{array}{l}\text { Liver - } \\
\text { Serum }+\end{array}$ & Liver + & Serum + & $\begin{array}{l}\text { Both Liver } \\
\text { and Serum - }\end{array}$ \\
\hline \multicolumn{8}{|l|}{ Chronic hepatitis } \\
\hline Chronic persistent hepatitis & 11 & 4 & 2 & - & $6(55 \%)$ & $4(36 \%)$ & $5(45 \%)$ \\
\hline Chronic aggressive hepatitis & 20 & 12 & 2 & - & $14(70 \%)$ & $12(60 \%)$ & $6(30 \%)$ \\
\hline Cirrhosis with little activity & 11 & 3 & 2 & - & $5(45 \%)$ & $3(27 \%)$ & $6(55 \%)$ \\
\hline Active cirrhosis & 34 & 21 & 6 & - & $27(79 \%)$ & $21(62 \%)$ & $7(21 \%)$ \\
\hline Total & 76 & 40 & 12 & 一 & $52(68 \%)$ & $40(57 \%)$ & $24(32 \%)$ \\
\hline \multicolumn{8}{|l|}{ Acute hepatitis } \\
\hline Fully developed stage & 7 & 1 & - & 4 & $1(14 \%)$ & $5(71 \%)$ & $2(29 \%)$ \\
\hline Later stage & 9 & 4 & - & - & $4(44 \%)$ & $4(44 \%)$ & $5(56 \%)$ \\
\hline Residual stage & 3 & - & - & - & - & - & $3(100 \%)$ \\
\hline $\begin{array}{l}\text { Acute stage with signs of possible transition } \\
\text { to chronicity }\end{array}$ & 5 & 3 & 一 & - & $3(60 \%)$ & $3(60 \%)$ & $2(40 \%)$ \\
\hline Total & 24 & 8 & - & 4 & $8(33 \%)$ & $12(50 \%)$ & $12(50 \%)$ \\
\hline Miscellaneous & 146 & - & - & 一 & - & - & $146(100 \%)$ \\
\hline
\end{tabular}

Table I Histological diagnosis and frequency of HBsAg obtained by serology and immunofluorescence 


\begin{tabular}{|c|c|c|c|c|c|c|c|c|c|c|c|c|c|c|}
\hline \multirow[t]{2}{*}{ Diagnosis } & \multirow[t]{2}{*}{$I F T$} & \multirow{2}{*}{$\begin{array}{l}\text { Sero- } \\
\log y\end{array}$} & \multirow[t]{2}{*}{ Number } & \multicolumn{2}{|c|}{ Age } & \multicolumn{2}{|c|}{ Sex } & \multirow{2}{*}{$\begin{array}{l}\text { Gamma- } \\
\text { globulins } \\
(\mathrm{g} / 100 \mathrm{ml})\end{array}$} & \multirow{2}{*}{$\begin{array}{l}S G O T^{1} \\
(I U / l)\end{array}$} & \multirow{2}{*}{$\begin{array}{l}S G P T^{1} \\
(I U / l)\end{array}$} & \multicolumn{4}{|c|}{ Auto-antibodies } \\
\hline & & & & $\mathrm{Mea}$ & an Range & $M$ & $F$ & & & & $A N F+$ & $A M A+$ & $S M A+$ & $(N o .)^{2}$ \\
\hline $\begin{array}{l}\text { Chronic } \\
\text { persistent } \\
\text { hepatitis }\end{array}$ & $\begin{array}{l}+ \\
+ \\
-\end{array}$ & $\begin{array}{l}+ \\
- \\
-\end{array}$ & $\begin{array}{l}4 \\
2 \\
5\end{array}$ & $\begin{array}{l}34 \\
54 \\
43\end{array}$ & $\begin{array}{l}17-48 \\
51-57 \\
30-58\end{array}$ & $\begin{array}{l}3 \\
1 \\
4\end{array}$ & $\begin{array}{l}1 \\
1 \\
1\end{array}$ & $\begin{array}{l}1.58 \pm 0.34 \\
1.48 \pm 0.52 \\
1.95 \pm 0.57\end{array}$ & $\begin{aligned} 37 & \pm 15 \\
9 & \pm 1 \\
21 & \pm 14\end{aligned}$ & $\begin{aligned} 69 & \pm 47 \\
9 & \pm 1 \\
39 & \pm 32\end{aligned}$ & $\frac{-}{2}$ & - & - & $\begin{array}{l}(3) \\
(1) \\
(4)\end{array}$ \\
\hline $\begin{array}{l}\text { Chronic aggress } \\
\text { hepatitis }\end{array}$ & $\begin{array}{l}\text { sive } \\
+ \\
+ \\
-\end{array}$ & $\begin{array}{l}+ \\
- \\
-\end{array}$ & $\begin{array}{r}12 \\
2 \\
6\end{array}$ & $\begin{array}{l}46 \\
64 \\
43\end{array}$ & $\begin{array}{l}15-58 \\
61-66 \\
16-53\end{array}$ & $\begin{array}{l}7 \\
1 \\
3\end{array}$ & $\begin{array}{l}5 \\
1 \\
3\end{array}$ & $\begin{array}{l}1.66 \pm 0.33 \\
2.01 \pm 0.50 \\
1.84 \pm 0.72\end{array}$ & $\begin{array}{l}61 \pm 44 \\
19 \pm 1 \\
49 \pm 60\end{array}$ & $\begin{array}{l}117 \pm 103 \\
35 \pm 9 \\
81 \pm 85\end{array}$ & $\frac{3}{2}$ & $\overline{-}$ & $\frac{-}{1}$ & $\begin{array}{l}(7) \\
(2) \\
(5)\end{array}$ \\
\hline $\begin{array}{l}\text { Cirrhosis with } \\
\text { little activity }\end{array}$ & $\begin{array}{l}+ \\
+ \\
-\end{array}$ & $\begin{array}{l}+ \\
- \\
-\end{array}$ & $\begin{array}{l}3 \\
2 \\
6\end{array}$ & $\begin{array}{l}51 \\
51 \\
55\end{array}$ & $\begin{array}{l}33-62 \\
37-64 \\
44-66\end{array}$ & $\begin{array}{l}2 \\
2 \\
3\end{array}$ & $\begin{array}{l}1 \\
0 \\
3\end{array}$ & $\begin{array}{l}2.20 \pm 0.93 \\
1.00 \pm 0.08 \\
1.16 \pm 0.26\end{array}$ & $\begin{array}{l}27 \pm 15 \\
17 \pm 0 \\
15 \pm 8\end{array}$ & $\begin{array}{l}33 \pm 18 \\
19^{3} \pm 3 \\
13^{3} \pm 2\end{array}$ & - & - & - & $\begin{array}{l}(1) \\
(1) \\
(3)\end{array}$ \\
\hline Active cirrhosis & $\begin{array}{l}+ \\
+ \\
-\end{array}$ & $\begin{array}{l}+ \\
- \\
-\end{array}$ & $\begin{array}{r}21 \\
6 \\
7\end{array}$ & $\begin{array}{l}53 \\
42 \\
45\end{array}$ & $\begin{array}{l}30-70 \\
22-63 \\
19-69\end{array}$ & $\begin{array}{r}17 \\
4 \\
4\end{array}$ & $\begin{array}{l}4 \\
2 \\
3\end{array}$ & $\begin{array}{l}2.19 \pm 0.95 \\
2.48 \pm 1.33 \\
1.68 \pm 0.64\end{array}$ & $\begin{array}{l}72 \pm 58 \\
76 \pm 64 \\
84 \pm 145\end{array}$ & $\begin{aligned} 101 & \pm 74 \\
80 & \pm 71 \\
80 & \pm 116\end{aligned}$ & $\begin{array}{l}1 \\
2 \\
-\end{array}$ & $\begin{array}{l}- \\
1 \\
2\end{array}$ & $\frac{-}{1}$ & $\begin{array}{r}(12) \\
(4) \\
(4)\end{array}$ \\
\hline
\end{tabular}

Table II Comparison of age, sex, biochemical features, and auto-antibodies in HBs Ag positive (in both liver and serum) and negative chronic hepatitis

1Normal values for SGOT and SGPT are below 19 IU/1 and 24 IU/1 respectively.

Numbers in brackets denote number of cases tested for auto-antibodies.

'Value significantly different from the group with positive serology $(P<0.05)$.

liver positive but serum negative, liver negative and serum positive, and liver and serum both negative. No consistent histological differences were found between HBsAg positive and negative hepatitis.

In chronic hepatitis, HBsAg was detected in 52 out of 76 patients $(68 \%)$ with immunofluorescence, and in 40 with radioimmunoassay (57\%). All HBsAgpositive cases could be detected with immunofluorescence; 12 out of $52(23 \%)$ could not be detected by radioimmunoassay on the serum. The detection of HBsAg in the liver of patients devoid of demonstrable circulating antigen was specific, as shown by specificity tests reported elsewhere (Ray et al, 1974); also, HBsAg was absent from the liver of 146 patients without hepatitis. The highest incidence of $\mathrm{HBsAg}$ was seen in chronic aggressive hepatitis $(70 \%)$ and in active cirrhosis $(79 \%)$. A higher frequency of $\mathrm{HBs} \mathrm{Ag}$ in more active forms, compared to less active forms, was found in chronic hepatitis with and without cirrhosis, and attained statistical significance $(P \sim 0.05)$. No significant correlation was found between the $\mathrm{HBsAg}$ status and levels of transaminases, gammaglobulins, and auto-immune antibodies (table II). In chronic hepatitis, 51 patients were males and 25 were females; $72 \%$ of males and $60 \%$ of females were HBsAg-positive.

In acute hepatitis, $\mathrm{HBsAg}$ was detected in 8 out of 24 patients $(33 \%)$ with immunofluorescence, and in 12 with radioimmunoassay (50\%). All HBsAgpositive cases could be detected with radioimmunoassay. In the fully developed stage, 4 out of 5 HBsAg-positive cases could be detected only by radioimmunoassay. The later stage of acute hepatitis, and acute hepatitis with signs of possible transition to chronicity, although histologically distinct, resembled chronic hepatitis in that HBsAg was detectable both in liver and in serum (table I).

\section{Discussion}

In chronic hepatitis as a whole, the frequency of HBsAg as obtained with immunofluorescence $(68 \%)$ and RIA (57\%) is comparable with the percentages reported from other parts of this continent (Wewalka et al, 1970; Bianchi et al, 1972). The latter results were obtained by estimating the circulating antigen with methods as sensitive as the complement fixation test and immunoelectro-osmophoresis. Thus the differences in the sensitivity of the techniques used cannot be invoked as the only cause of variation in the frequency of $\mathrm{HBsAg}$ in chronic hepatitis (Cooksley et al, 1972; Reed et al, 1973). The frequency of HBsAg in Belgium, as determined by radioimmunoassay, is $0.4-0.5 \%$ (C. Vermylen and J. Desmyter, unpublished data) which is comparable to figures reported from Australia (Mason et al, 1972) and the USA (Ling and Overby, 1972). Therefore the high frequency of $\mathrm{HBsAg}$ obtained in chronic hepatitis in the population examined cannot be ascribed to a high prevalence of $\mathrm{HB}$ virus infection in this area. The variation in frequency may be due to differences in genetic make-up of the patients (Reed et al, 1973) or to other unknown factors. Whatever the explanation may be, our observations show a high frequency of HBsAgpositive cases in chronic hepatitis.

HBsAg-positive patients with chronic hepatitis 
have been described as both younger (Bianchi et al, 1972) and older (Sherlock et al, 1970) than HBsAgnegative patients. Gammaglobulin levels have been reported to be lower in HBsAg-positive cases than in HBsAg-negative cases (Bulkley et al, 1970) and autoantibodies to be absent in the blood of HBsAgpositive cases but not in HBsAg-negative cases (Bulkley et al, 1970; Wright, 1970; Cooksley et al, 1972). Such differences were not found in the present study.

There were no morphological differences between HBsAg-positive and HBsAg-negative biopsies. The highest incidence of $\mathrm{HBsAg}$ was seen in active cirrhosis, which was the prevalent type in this series. These findings contrast with those of Bianchi et al (1972), who have reported more frequent cirrhotic changes in antigen-negative groups. HBsAg was present more frequently in patients with chronic aggressive hepatitis or active cirrhosis than in patients with chronic persistent hepatitis or less active cirrhosis; yet, in HBsAg-positive patients, the amount of HBsAg in hepatocytes as seen by immunofluorescence was higher in less active forms than in aggressive forms (Ray et al, 1976).

Twelve patients had HBsAg which could be detected in the liver but not in their serum. These cases could not be sharply segregated from others on the basis of histological, epidemiological, and biochemical parameters.

We have used the most sensitive methods available to estimate $\mathrm{HBsAg}$ in tissue and serum; yet a number of cases of chronic hepatitis remain HBsAg-negative. This does not necessarily mean that $\mathrm{HB}$ virus infection is not associated with $\mathrm{HBsAg}$-negative cases, since longitudinal studies and the detection of antibodies against $\mathrm{HB}$ virus may reveal additional associations.

In the 24 patients with the histological diagnosis of acute hepatitis, $\mathrm{HBsAg}$ was found in $50 \%$ in the serum, and in $33 \%$ in the liver. Our results with immunofluorescence and RIA in acute hepatitis are comparable with other observations (Edgington and Ritt, 1971; Mossor-Ostrowska et al, 1974). In particular, in fully developed acute hepatitis, HBsAg was much more readily detectable in the serum than in the liver, in contrast to the later stage of acute hepatitis and acute hepatitis with signs of longer duration, in which $\mathrm{HBsAg}$ was detected in tissue and in serum, and to chronic hepatitis, in which HBsAg was more readily detectable in tissue. These observations are consistent with the rare finding of $\mathrm{HBsAg}$ in acute hepatitis by immunofluorescence (Krawczyński et al, 1972; Gudat et al, 1975) and by electronmicroscopy (Nelson et al, 1970). This supports the hypothesis that HBsAg-positive cells are cleared at high efficiency in acute hepatitis by normal immunological mechanisms (Dudley et al, 1972; Reed et al, 1974).

We are indebted to Dr L. Broeckaert and Dr E. Stevens for valuable help and suggestion, and we thank Miss Rita Dereymaeker and A. De Boeck for technical assistance, and Mrs M. VeulemansWeckx for typing the manuscript.

This study was supported by grants from Nationaal Fonds voor Wetenschappelijk Onderzoek and the Fonds voor Geneeskundig Wetenschappelijk Onderzoek of Belgium.

\section{References}

Bianchi, P., Bianchi Porro, C., Coltorti, M., Dardanoni, L., Del Vecchio Blanco, C., Fagiolo, U., Farini, R., Menozzi, I., Naccarato, R., Pagliaro, L., Spanò, C., and Verme, G. (1972). Occurrence of Australia antigen in chronic hepatitis in Italy. Gastroenterology, 63, 482-485.

Bianchi, L., De Groote, J., Desmet, V. J., Gedigk, P., Korb, G., Popper, H., Poulsen, H., Scheuer, P. J., Schmid, M., Thaler, H., and Wepler, W. (1971). Morphological criteria in viral hepatitis. Review by an international group. Lancet, 1, 333-337.

Bradburne, A. F. and Desmyter, J. (1974). Radioimmunoassay for HBs (Australia) antigen: specificity and application to subtyping. Proceedings of the VIth International Congress of Infectious and Parasitic Diseases, vol. 2, pp. 1419. Academy of Medicine, Warsaw.

Bulkley, B. H., Heizer, W. D., Goldfinger, S. E., Isselbacher. K. J., and Shulman, N. R. (1970). Distinctions in chronic active hepatitis based on circulating hepatitis-associated antigen. Lancet, 2, 1323-1326.

Cérat, G., Richer, G., Viallet, A., Côté, J., Robert, J., and Turgeon, F. (1973). Detection of Australia antigen in liver biopsies by immunofluorescence. Canad. med. Ass. J., 108, 981-984.

Cooksley, W. G. E., Powell, L. W., Mistilis, S. P., Olsen, G., Mathews, J. D., and Mackay, I. R. (1972). Australia antigen in active chronic hepatitis in Australia: results in 130 patients from three centres. Aust. N.Z.J. Med., 3, 261265.

Coyne (Zavatone), V. E., Millman, I., Cerda, J., Gerstley, B. J. S., London, T., Sutnick, A., and Blumberg, B. S. (1970). Localization of Australia antigen by immunofluorescence. J. exp. Med., 131, 307-319.

De Groote, J., Desmet, V. J., Gedigk, P., Korb, G., Popper, H., Poulsen, H., Scheuer, P. J., Schmid, M., Thaler, H.. Uehlinger, E., and Wepler, W. (1968). A classification of $O$ chronic hepatitis. Lancet, 2, 626-628.

Desmet, V. (1973). Chronic hepatitis (including primary biliary cirrhosis). In The Liver edited by $\mathrm{E}$. A. Gall and F. K. Mostofi. Williams and Wilkins, Baltimore.

Dudley, F. J., Fox, R. A., and Sherlock, S. (1972). Cellular immunity and hepatitis-associated Australia antigen in liver disease. Lancet, 1, 723-726.

Edgington, T. S. and Ritt, D. J. (1971). Intrahepatic expression of serum hepatitis virus-associated antigens. J. exp. Med., 134, 871-885.

Gudat, F., Bianchi, L., Sonnabend, W., Thiel, G., Aenishaenslin, W., and Stalder, G. A. (1975). Pattern of core and surface expression in liver tissue reflects state of specific immune response in hepatitis B. Lab. Invest., 32, $1-9$.

Hadziyannis, S., Vissoulis, Ch., Moussouros, A., and 
Afroudakis, A. (1972). Cytoplasmic localization of Australia antigen in the liver. Lancet, 1, 976-979.

Krawczyński, K., Nazarewicz, T., Brzosko, W. J., and Nowoslawski, A. (1972). Cellular localization of hepatitisassociated antigen in livers of patients with different forms of hepatitis. J. infect. Dis., 126, 372-377.

Ling, C. M. and Overby, L. R. (1972). Prevalence of hepatitis $B$ virus antigen as revealed by direct radioimmunoassay with 125 I-antibody. J. Immunol., 109, 834-841.

Mason, E. C., Shaw, A. E., Harding, M. J., and Witney, K. J. (1972). High-voltage immuno electroosmophoresis in Australia antigen screening of blood donors. Med. J. Aust., 1, 1020-1023.

Mossor-Ostrowska, J., Sowa, J., and Nazarewicz, T. (1974). Auto-antibodies in the serum and Australia antigen both in the serum and in tissue in diseases of the liver (Abstract). In Proceedings of the VIth International Congress of Infectious Diseases, p. 100. Academy of Medicine, Warsaw.

Nelson, J. M., Barker, L. F., and Danovitch, S. H. (1970). Intranuclear aggregates in the liver of a patient with serum hepatitis. Lancet, 2, 773-774.

Prince, A. M. (1971). Role of serum hepatitis virus in chronic liver disease. Gastroenterology, 60, 913-921.

Prince, A. M., Hargrove, R. L., Szmuness, W., Cherubin, C. E., Fontana, V. J., and Jeffries, G. H. (1970). Immunologic distinction between infectious and serum hepatitis. N. Engl. J. Med., 282, 987-991.

Ray, M. B., Desmet, V. J., Fevery, J., de Groote, J., Bradburne, A. F., and Desmyter, J. (1976). Distribution patterns of hepatitis B surface antigen (HBsAg) in the liver of hepatitis patients. J. clin. Path., 29, 94-100.
Ray, M. B., van Damme, B., and Desmet, V. J. (1974). Evaluation of a modified fluorescent technique for the detection of Australia antigen in liver tissue. J. immunol. Meth., 3, 47-52.

Rake, M. O., Murray-Lyon, I. M., Ansell, I. D., and Williams, R. (1969). Improved liver-biopsy needle. Lancet, $2,1283$.

Reed, W. D., Eddleston, A. L. W. F., Stern, R. B., Williams, R., Zuckerman, A. J., Bowes, A., and Earl, P. M. (1973). Detection of hepatitis-B antigen by radioimmunoassay in chronic liver disease and hepatocellular carcinoma in Great Britain. Lancet, 2, 690-694.

Reed, W. D., Eddleston, A. L. W. F., and Williams, R. (1974). Immunopathology of viral hepatitis in man. Progr. med. Virol., 17, 38-76.

Sherlock, S., Fox, R. A., Niazi, S. P., and Scheuer, P. J. (1970). Chronic liver disease and primary liver-cell cancer with hepatitis-associated (Australia) antigen in serum. Lancet, 1, 1243-1247.

Shulman, N. R. and Barker, L. F. (1969). Virus-like antigen, antibody, and antigen-antibody complexes in hepatitis measured by complement fixation. Science, 165, 304-306.

Sutnick, A. I., London, W. T., and Blumberg, B. S. (1969). Australia antigen and the quest for a hepatitis virus. Amer. J. dig. Dis., 14, 189-194.

Velasco, M. and Katz, R. (1970). Hepatitis-associated antigen in chronic liver disease. (Letter). Lancet, 1, 779.

Wewalka, F., Gnan, F., Krassnitzky, O., and Pesendorfer, F. (1970). Au/SH-antigen in liver disease. Vox Sang. (Basel), 19, 311-317.

Wright, R. (1970). The Australia antigen jn chronic active hepatitis. Vox Sang. (Basel), 19, 320-326. 